Contributions:

A Study design/planning

B Data collection/entry

C Data analysis/statistics

D Data interpretation

E Preparation of manuscript

F Literature analysis/search

$\mathrm{G}$ Funds collection

\title{
NEW PERSPECTIVES ON OLD IDEAS IN HEARING SCIENCE: INTRALABYRINTHINE PRESSURE, TENOTOMY, AND RESONANCE
}

\author{
Andrew Bell ${ }^{A D E F}$
}

Corresponding author: Eccles Institute of Neuroscience, John Curtin School of Medical Research, Australian National University, Canberra, ACT 2601, Australia, email: andrew.bell@anu.edu.au

\begin{abstract}
It is natural to think that hearing science progresses linearly, making new discoveries and opening up fresh vistas. But it doesn't always happen that way, and false starts are not uncommon. Here a brief survey is made of ideas about the mechanics of the middle ear and cochlea that appeared before 1900 but which have now, after a period of neglect, attracted renewed attention. Luminaries of 19th-century otology - Helmholtz and Weber-Liel - are used to illustrate the case. Three of their ideas - the mode of action of the middle ear muscles, the role of intralabyrinthine pressure, and resonance in the cochlea - were central to their thinking but for various reasons were later set aside. Notably, however, some old perspectives - such as the value of tenotomy in Meniere's disease - appear consistent with recent suggestions. Another discovery of modern science - Piezo1, a piezoelectric channel protein shaped like a propeller - strengthens the idea that pressure-sensing is crucial to cochlear function and indeed that Helmholtz's original resonance theory might still have merit.
\end{abstract}

Key words: middle ear $\bullet$ ossicles $\bullet \operatorname{cochlea} \bullet$ otology $\bullet$ intralabyrinthine fluids $\bullet$ pressure $\bullet$ Meniere's disease $\bullet$ tenotomy $\bullet$ ion channels $\bullet$ Piezo 1

\section{NUEVAS PERSPECTIVAS EN VIEJAS IDEAS EN LA CIENCIA DE LA AUDICIÓN: PRESIÓN INTRALABERÍNTICA, TENOTOMÍA Y RESONANCIA}

\section{Resumen}

Es natural pensar que la ciencia de la audición progresa linealmente, haciendo nuevos descubrimientos y abriendo nuevas y frescas perspectivas. Pero no siempre sucede así, y desafortunadamente los inicios falsos no son infrecuentes. Aquí se hace una breve encuesta de ideas sobre la mecánica del oído medio y la cóclea que aparecieron antes de 1900 pero que ahora han atraído una atención renovada. Los ilustrados de la otología del siglo XIX, Helmholtz y Weber-Liel, son usados para explicar el caso. Tres de sus ideas (el método de acción de los músculos del oído medio, el papel de la presión intralaberíntica y la resonancia en la cóclea) fueron fundamentales para sus ideas, pero por múltiples razones se dejaron de lado más adelante. Sin embargo, admirablemente, algunas perspectivas antiguas, como el valor de la tenotomía en la enfermedad de Meniere, parecen ser sólidas con las conjeturas recientes. Otro descubrimiento de la ciencia moderna (Piezol, una proteína de canal piezoeléctrico con forma de hélice) refuerza la idea de que la detección de presión es crucial para la función coclear.

Palabras clave: presión intralaberíntica • enfermedad de Meniere • tenotomía • Piezo1

\section{НОВЫЙ ВЗГЛЯД НА СТАРЫЕ ИДЕИ В НАУКЕ О СЛУХЕ: ВНУТРИЛАБИРИНТНОЕ ДАВЛЕНИЕ, ТЕНОТОМИЯ И РЕЗОНАНС}

\begin{abstract}
Аннотация
Принято считать, что наука о слухе развивается постепенно, совершаются новые открытия и появляются новые перспективы. Но это происходит не всегда так, неудачи не являются редкостью. В данной статье представлен краткий обзор идей о механике среднего уха и улитки, которые появились еще до 1900 года, а теперь им снова уделяется пристальное внимание. Чтобы проиллюстрировать данное явление, был использован пример выдающихся светил отологии 19 века - Гельмгольца и Вебер-Лиела. Как работают мышцы среднего уха, роль внутрилабиринтного давления, резонанс в улитке - это те ключевые идеи, на которые они опирались, но которые со временем по разным причинам стали неактуальными. Стоит обратить внимание, что некоторые из давних идей, например, значение тенотомии в болезни Меньера, соответствуют современным исследованиям. Ещё одно открытие современной науки - Piezo1, пьезоэлектрический канальный белок в форме винта, - подтверждает мнение о том, что давление имеет решающее значение в функционировании улитки.
\end{abstract}

Ключевые слова: внутрилабиринтное давление • болезнь Меньера • тенотомия • Piezol. 


\title{
NOWE PERSPEKTYWY ODNOŚNIE DAWNYCH IDEI W NAUCE O SŁUCHU: CIŚNIENIE WEWNĄTRZBŁĘDNIKOWE, TENOTOMIA I REZONANS
}

\begin{abstract}
Streszczenie:
Naturalnym jest myślenie, że nauka o słuchu postępuje liniowo, dokonuje się nowych odkryć i otwierają się nowe perspektywy. Ale nie zawsze tak się dzieje, a niepowodzenia nie są rzadkością. Oto krótki przegląd idei dotyczących mechaniki ucha środkowego i ślimaka , które pojawiły się przed rokiem 1900, a teraz ponownie stają się źródłem zainteresowania. W celu zobrazowania tej sprawy wykorzystano przykład wybitnych twórców 19-wiecznej otologii - Helmholtza i Webera-Liela. Trzy z ich idei - sposób działania mięśni ucha środkowego, rola ciśnienia wewnątrzbłędnikowgo, rezonans w ślimaku - były kluczowe dla ich myślenia , ale z różnych powodów, zostały później odłożone na bok. Warto jednak zauważyć, że niektóre dawne idee- takie jak wartość tenotomii w chorobie Maniera - wydają się zgodne z ostatnimi wnioskami. Kolejne odkrycie współczesnej nauki - Piezol, piezoelektryczne białko kanałowe w kształcie śmigła - może wspierać pogląd, że wykrywanie ciśnienia ma kluczowe znaczenie dla funkcjonowania ślimaka.
\end{abstract}

Słowa kluczowe: ciśnienie wewnątrzbłędnikowe • choroba Maniera • tenotomia • Piezo1

\section{Introduction}

Great advances have been made in hearing science, particularly in terms of the noninvasive measurement of otoacoustic emissions and the underlying theory of cochlear mechanics. However, the case can also be made that in some areas important findings and fundamental ideas have disappeared from sight. Two such examples are the resonance theory of hearing, put forward most forcefully by Helmholtz in the 1850s (1), and the role of the middle ear muscles in protecting the cochlea from high-level sound, seen by Gellé in the 1880s as involving regulation of pressure of the intralabyrinthine fluids (2).

The context here are recent papers which argue, firstly, that Helmholtz's resonance theory can provide potentially valuable insights into how the cochlea works, even in the light of Békésy's more recent traveling wave theory. Secondly, there are papers on the cause of Meniere's disease (MD), a malady which has puzzled otologists since 1861 when Prosper Meniere identified the distinctive triad of vertigo, hearing loss, and tinnitus. It is surprising that a set of recent papers find that tenotomy - cutting the tendon of the tensor tympani muscle - provides therapeutic benefits (3-5). A recent hypothesis makes the case that this is because MD is caused by spasm of the tensor tympani muscle, which produces excessive hydraulic pressure in the labyrinthine fluids (6). The logic is that tenotomy is a direct way of preventing excess pressure, and this same idea can be clearly found in the works of Gellé, Weber-Liel, Helmholtz, and other 19th-century otologists.

The first topic - the aptness of the resonance theory of hearing - is an extensive one, and the full details are not discussed here. As background, the reader is referred to recent work which canvasses its merits (7-9), but later in this paper some new lines of evidence are outlined which appear to support resonance. In summary, first there is the finding that the outer hair cell contains piezoelectric ion channels shaped like propellers, channels whose structure suggests they sense hydraulic pressure $(10,11)$. Second, there are "reverse polarity" channels which, in response to a water jet stimulus, act in antiphase (12) to normal channels; the significance here is that both sorts of channels might work together to establish a standing wave resonance between rows of outer hair cells. The idea, elaborated below, is that each row of outer hair cells could, if it acted in antiphase to its neighbouring rows, set up a series of nodes and antinodes which would then act as the "interdigital fingers" of an active surface acoustic wave (SAW) resonator inside the cochlea (13). Finally, a recent paper (14) finds that cochlear impulse responses seem to be built up from multiple resonating elements, a result directly supporting the resonance picture.

A broader issue is the role of the middle ear muscles in protecting the cochlea from overload. Here, a long-neglected theory originating in the 19th century - that the middle ear muscles act by pressing on the stapes and raising intralabyrinthine pressure (2) - will be revisited. This paper outlines the mechanism by which protection is thought to be achieved, a mechanism that appears to have merit in explaining the cause of Meniere's disease (as a recent paper (6) suggests). When one considers the intralabyrinthine pressure theory in the context of tenotomy, another idea of 19 th century origin, the conclusion is that something of value can be learnt from examining what the old textbooks had to say.

\section{Intralabyrinthine pressure}

The idea that contraction of the middle ear muscles causes the stapes to press in on the oval window and raise the static pressure of the fluids inside the otic capsule is a concept that can be traced back to Politzer in 1861 (15) who noted that electrical stimulation of the middle ear muscles led to changes in middle ear pressure and, he inferred, corresponding changes in labyrinthine pressure. Lucae in 1866 then proposed that natural contraction of the tensor tympani, such as through the acoustic reflex, affected low-frequency hearing through an effect on labyrinthine pressure (15), and this mechanism was taken up and promoted by Gelle in the 1880s (2). At the turn of the century Zimmerman made the crucial insight that pressure might somehow control the vibration of the basilar membrane fibres, but subsequently the theory, for various reasons, gradually fell from favour. The modern view is that protection is achieved through stiffening of ossicular joints and an increase in impedance of the annular ligament surrounding the stapes (15). A major reason was the rise of Békésy's traveling wave, an entity whose mechanics are assumed to be unaffected by pressure. Today, of course, it is known that the cochlea is an electronic device containing a 'cochlear amplifier' which could conceivably be sensitive to pressure, as Zimmerman supposed, and a theory 
of how outer hair cells are pressure sensors, not displacement sensors, has been developed $(16,17)$.

A full account of the intralabyrinthine pressure theory is given in (2). With knowledge gained over the years, the theory has now been refined and given a numerical basis. One suggestion put forward in the more recent work is that there is a direct relationship between static hydraulic pressure generated by contraction of the middle ear muscles and the observed frequency of otoacoustic emissions (a figure of about $20 \mathrm{~Hz} / \mathrm{kPa}$ appears consistent with a number of different observations). In later work (6), a direct numerical link between middle ear muscle force and intralabyrinthine pressure was proposed, ultimately arriving at the conclusion that a contraction of the tensor tympani could, by exerting a force of 1 gram weight $(0.01$ newton) on the stapes, produce a pressure of $3 \mathrm{kPa}$ in the labyrinthine fluids. In this way, a physical framework can be given for how the middle ear muscles might quickly and effectively prevent cochlear overload. Although the idea has not yet been the focus of modern investigation, it does provide a physical starting point for studying the subtle interplay between the middle ear and the cochlea.

\section{Meniere's disease, then and now}

The theory sketched above of how the middle ear muscles might control the hydraulic pressure surrounding the hair cells in the labyrinth (and hence their sensitivity) has several interesting ramifications. One important implication is the perspective it offers on Meniere's disease (MD). $\mathrm{MD}$ is a disabling disorder whose cause has eluded investigators for more than a century (18). Sufferers experience sudden random attacks of variable ferocity during which they simultaneously experience vertigo, fluctuating hearing loss, and tinnitus, often accompanied by a feeling of pressure in the ears (19).

Recently, consideration of all the symptoms and circumstances surrounding MD has led this researcher to the conclusion that Meniere's disease is not caused by endolymphatic hydrops, as usually believed, but by pressure originating from a force outside the cochlea - from the middle ear muscles (6). After surveying the evidence, the case is made that Meniere's and all its symptoms are triggered by spasm or dystonia of the middle ear muscles, which forcefully presses the stapes into the oval window and leads to a debilitating rise in intralabyrinthine pressure. The sudden rise in hydraulic pressure compresses hair cells in the labyrinth, in this way causing fluctuating hearing loss, vertigo, and tinnitus, with the feeling of aural fullness originating directly from the sensory muscle spindles.

The middle ear muscle theory of MD points out that the otic capsule is a sealed cavity within solid bone which is filled with incompressible fluid, an arrangement which means that the muscles work virtually isometrically against the compliance of the round window. Based on a compliance of $10^{-13} \mathrm{~m}^{5} / \mathrm{N}$, it can be calculated that a contractile force of $1 \mathrm{~g}$ wt $(0.01 \mathrm{~N})$ will cause a pressure rise of $3 \mathrm{kPa}$ and distention of the round window by a few tenths of a millimetre. The theory therefore explains why, in order to work isometrically, the tensor tympani has special properties such as very short muscle fibres.
The same paper also supplies an answer to the question of how a pressure of $3 \mathrm{kPa}$ could cause outer hair cells (OHCs) to collapse and lose their characteristic electromotility. OHCs are sealed vessels suspended in the fluids of the cochlea and are inflated with an internal turgor pressure of $1 \mathrm{kPa}$, so if the intralabyrinthine pressure should rise above $1 \mathrm{kPa}$, the cells can no longer maintain turgor and they collapse. In such a situation, the gain of the cochlear amplifier, which depends on the outer hair cells, depends directly on pressure, as Zimmerman suspected. The theory also explains: 1 ) why attacks are sudden; 2) the similarity between MD and tonic tensor tympani syndrome; 3) why surgical pressure applied to the otic capsule creates Meniere-like effects; 4) the effects of voluntary contraction of the tensor tympani; and 4) the wide-ranging effects resulting from section of the muscle tendons.

To elaborate the last point, recent work with Meniere's patients has provided compelling evidence that the middle ear muscles are involved in Meniere's attacks. In two seminal papers, one from 2003 (3) and another from 2012 (5), it has been found that tenotomy of the middle ear muscles provides effective relief from Meniere's attacks (and that dizziness is markedly reduced). This can be interpreted as evidence that Meniere's disease is caused by an excess of intralabyrinthine pressure, perhaps due to dysfunction of the middle ear muscle control loop (6).

Of interest here is the concept of endolymphatic hydrops $(\mathrm{EH})$ as the basis of MD, which Weber-Liel anticipated with his idea of an "overfilled" labyrinth (20, p.224). The EH terminology actually dates only from 1938, and it is worth noting that this concept has been difficult to substantiate. A recent evaluation in the Cochrane data base found no evidence that surgical interventions to alleviate EH had been successful (21). Hallpike and Cairns (22) used four fixed, decalcified, and sectioned temporal bones from two patients to make the case that the delicate Reissner's membrane appeared to be distended in cases of MD. Given the opportunity for artefacts, the question arises of whether modern-day otologists have perhaps been overly zealous in seizing on a plausible explanation for what is a puzzling malady.

Of course, there is now additional evidence for the EH notion, most directly from MRI studies which appear to indicate an enlarged endolymphatic volume (23). However, the volumes involved are exceptionally minute (microliters at most), and accurate quantitative measurements are still not possible using current MRI resolutions. Most significantly, these findings involve only correlations, and while the majority of cases of MD do indicate $\mathrm{EH}$ (24), it is important to remember that there are cases of $\mathrm{EH}$ where there is no MD (25). So on the basis of available data it cannot be confidently stated that $\mathrm{EH}$ causes $\mathrm{MD}$, only that the two conditions tend to co-occur. For example, a possible explanation for the observed correlation could be that the pressure generated by the middle ear muscles somehow leads to an increase in endolymph volume, or maybe to increased absorption of MRI contrast agent. More study of the diagnostic power of MRI - the area under the ROC curve - in cases of MD is very much needed in order to validate the $\mathrm{EH}$ hypothesis. 
So far as tenotomy is concerned, the literature has been much more cautious in its reaction to the 2003 and 2012 studies, possibly because of the long-standing view, now under challenge, that the disease must be due to endolymphatic hydrops. The merits of the case are set out in (6), but the aspect highlighted in the section below is how tenotomy was a practice developed first in the 19th century by Weber-Liel and then, for various reasons, abandoned.

\section{Weber-Liel and tenotomy}

In the early 1870 s, Weber-Liel published a series of findings which caused considerable controversy in otology $(20,26$, 27). In these articles, Weber-Liel described in considerable detail how sectioning the tendon of the tensor tympani could cure many hearing afflictions - dizziness, "subjective noises in the ear", and deafness due to an "overfilled" labyrinth and "irritations by intralabyrinthal pressure". He made it clear how "an anomalously strong tension of the muscle", and the pressure it sustains, necessarily lessens the "oscillatory capacity of the intralabyrinthal apparatus". He likened the effects of increased pressure to what happens if a surgeon puts pressure on the stapes when the other ossicles are missing: patients immediately report noises in the ear, and sometimes become dizzy.

These symptoms are similar to what happens during a Meniere's attack, and Weber-Liel's account of tenotomy, based on hundreds of cases, provides a direct explanation for why middle ear muscles may be responsible for Meniere's disease. So why did this explanation not gain traction? And why were the much later findings by Franz, Loader, and colleagues in the 21st century also insufficient to give the pressure theory at least some credence?

It appears that the claims made for tenotomy were excessive - Meniere's is a relatively rare condition and tenotomy is not a general cure-all for deafness and tinnitus and the drawbacks of surgical complications, in an age before antibiotics, were too strong. Although there were

Figure 1. Middle ear muscles, outer hair cells, and propellers: how outer hair cells detect surrounding pressure variations. (A) When the middle ear muscles contract (yellow, pink), they cause pressure changes within the cochlear fluids (blue). (B) An outer hair cell, immersed in the fluid, senses pressure changes (blue arrows) via piezoelectric channels set in its cell walls. It is assumed that the walls are rigid, but that certain components of the cell, such as Hensen's body or the subsurface cisterns, are compressible. The cuticular pore, with its rudimentary kinocilium, is a compliant spot. (C) Pressure-sensitive channels - specifically Piezo1 - are located in the walls and/or cuticular plate of the outer hair cell. They are shaped like propellers, strongly implying they rotate under transmembrane pressure, thereby gating ions through the centre of the channel. Illustrations used with permission: $A$, adapted from (34) (C) 1959 Taylor and Francis Ltd; B, adapted from (35) (C) 1986 Elsevier; C, from (11) (C 2015 Springer Nature. enthusiastic advocates, the technique was difficult to perform and it steadily fell into disrepute (28, pp. 419-428, 29 , Ch. 17, 30). Now that we have antibiotics, and a definite, testable theory has been framed as to the physics and physiology, it may be time to re-evaluate the merits of the technique.

\section{Helmholtz and the mechanics of the ossicles}

Hermann von Helmholtz was both a surgeon and a scientist of the first rank. He was the first to frame a resonance theory of hearing based on scientific principles (1), and made many other contributions to our knowledge of the ear. His resonance theory was received enthusiastically, and this work is still required reading for students today, even if widely regarded as outmoded. His theory was overtaken by Békésy's traveling wave theory, largely because scientists could not understand how tiny strings in the ear could vibrate sympathetically and sharply to incoming sound when they were immersed in fluid. Nowadays, we know that the cochlea is an active device - it contains a "cochlear amplifier" - and an updated version of the resonance theory involving resonance between sound pressure and reactive outer hair cells has been proposed (9). This recent work puts Helmholtz's core idea on a new footing and shows how, once the distinction in cochlear mechanics between phase delay and group delay is made clear, a graded set of resonators can physically act in a similar way to a traveling wave $(13,31,32)$.

Here we wish to highlight another noteworthy achievement of Helmholtz which is contained in his detailed work "The mechanism of the ossicles and the membrana tympani" (33). An important concept that Helmholtz draws attention to is Pascal's principle: that whenever a confined incompressible fluid is subject to pressure, the pressure is instantly transmitted to every part of the fluid. As he says, "an incompressible fluid... contained within solid walls [means that] every impulse which reaches any part of its surface communicates itself immediately throughout the whole fluid, and sets every part instantly in motion" (ibid., p.106).
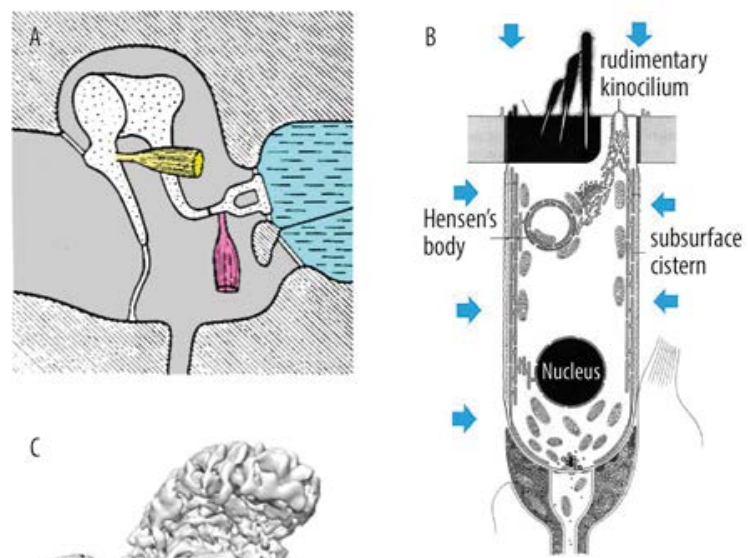
Applied to the cochlea - a cavity within solid bone and filled with incompressible liquid - the principle leads to the idea that the otic capsule is a fluid-filled chamber whose only appreciable outlets are the oval and round windows. So when the stapes presses on the oval window, it instantly raises the hydraulic pressure inside, with the only point of give being the round window, and the pressure is instantly transmitted to all the sensing cells suspended within. This is the basis of the intralabyrinthine pressure theory: the sensitivity of the sensing cells is controlled by the pressure exerted by the tensor tympani on the stapes, and is only relieved by the compliance of the round window and the compressibility of the cells themselves - assuming they contain small compressible volumes, such as Hensen's body or subsurface cisterns, within their essentially rigid walls (Figure 1).

In this regard, the recent discovery of an apparent pressuresensitive channel in the cuticular plate of outer hair cells takes on added significance (12). Taking note of Helmholtz's description of Pascal's principle, it raises the possibility that the middle ear muscles could be part of a hydraulic system that might regulate outer hair cell sensitivity via the effect of a pressure gradient set up across the wall of the cell. Because water is nearly incompressible, only a very small displacement of the stapes is enough to appreciably change the hydraulic pressure within the cochlea, in this way bringing about a quick and direct way of simultaneously adjusting the gain of the cochlear amplifiers within all 12,000 outer hair cells. The speculation is made that piezo channels found within OHCs underlie the basis of that pressure sensitivity.

Ge and colleagues have recently discovered $(10,11)$ that certain piezoelectric channels - specifically Piezo1 - are shaped like a propeller, as shown in Figure 1. The exact mode of action of the channel is still unclear, but at face value it appears it may detect pressure by rotating - a natural inference for a propeller-shaped sensing structure, especially one which could be set in the side wall or top plate of an outer hair cell. This conjecture calls for further investigation. One requirement for such a pressure sensor to operate efficiently is that there be some compressible element within the cell, and one possible candidate may be Hensen's body (the layered organelle seen in Figure 1B).

Returning to Helmholtz, it is instructive to consider how small the stapes displacements actually are. Helmholtz measured static ossicular displacements by attaching fine needles to each of the middle ear bones. He found that the displacements of the stapes were but small fractions of a millimeter - between 0.033 and $0.035 \mathrm{~mm}$ (ibid., p. 132). These minute dimensions should be compared to modern laser-based experiments where oscillating stapes displacements of $40-60 \mu \mathrm{m}$ at $150 \mathrm{~dB}$ have been measured (36). Helmholtz notes the "powerful pull" exerted by the tensor tympani and how its contraction presses the stapes "into the fenestra ovalis upon the labyrinth water" (p. 130). From his experience of yawning, he reports the sound of a loud muscular murmur, which he supposes is due to contraction of the tensor tympani, and during which "external sounds are much dulled". He surmises that the pressure in the labyrinth must increase with tensor contraction, and he attempts to measures the rise in pressure, obtaining figures of $0.4-0.9 \mathrm{~mm}$ of water (just 4-9 Pa). This result is one where Helmholtz's experimental technique can be criticised, for the manometric method severely underestimates the true pressure. If a high impedance pressure gauge had been used instead of a manometer whose volume of tubing lets the pressure dissipate, a more realistic figure of several kilopascal would have been measured (6). Again, it helps to appreciate that water is incompressible, the volume of the otic capsule is less than $0.2 \mathrm{~mL}$, and the displacements of the cochlear windows are only several micrometers. The difficulty in accurately measuring intralabyrinthine pressure in vivo is a possible reason the key role of this parameter has largely escaped notice.

Helmholtz's monograph makes other significant contributions, particularly in how there is a "cog wheel" in the articulation of the malleus and incus, and that there are distinctive short muscle fibres in the tensor tympani. One implication of the cogwheel is that it might quickly enable pressure to be ratcheted up by repetitive contractions of the tensor tympani, and this is another aspect that deserves fuller investigation.

\section{Towards a new resonance model of the cochlea}

Helmholtz is well remembered for his seminal resonance theory of hearing which allowed hearing science to make great strides forward. However, despite its undoubted merits, the theory was later overtaken by Békésy and his traveling wave theory. Be that as it may, the elegance of the resonance explanation continues to attract interest. The advantages and drawbacks of the two theories have been the subject of a number of works $(7-9,31,37)$. One modern version of the resonance theory is the surface acoustic wave (SAW) model, already mentioned, which assumes that tiny parcels of fluid are pumped back and forth between the rows of outer hair cells (38-40). Each OHC sits at an antinode, so a triplet of them creates a whole-wavelength standing wave which, like a vibrating string (or more accurately, a xylophone bar), resonates to incoming sound. Unlike Helmholtz's piano strings, however, the resonating elements are not structures but spaces between the OHCs. Details of the SAW model can be found in (13, $41,42)$. A recent publication (14) also supports the resonance interpretation. This paper has reexamined the distinctive waveform made by the cochlea in response to a click - its impulse response - and in the experimental cases available for analysis a surprising property was seen to emerge. All the impulse responses appeared to be made up of several more basic waveforms (gammatones) - a result which leads to the interpretation that each gammatone may be the signature of an individual resonator. When simultaneously struck with a sharp impulse, a set of such resonators would, like an array of wind chimes, give rise to the observed compound waveform. Thus, Helmholtz's key notion of Fourier analysis through sympathetic resonance - parallel inputs to a multistringed piano - is offered direct support.

There is one distinctive aspect of the SAW model which calls for attention, and that is the requirement that the middle row of outer hair cells, $\mathrm{OHC} 2$, act in antiphase to the surrounding rows, $\mathrm{OHC} 1$ and $\mathrm{OHC} 3$, an arrangement that permits resonance to build up through positive 
feedback. In this context, it is relevant to highlight the recent discovery of "reverse polarity" mechanotransducer channels in the apical membrane of OHCs (12). These previously undetected channels can be activated by membrane stretch or a fluid jet, suggesting they may have properties in common with the Piezo1 channel described earlier. In this case, it is really pressure - not stretch or fluid motion - which is activating the channels. If this is correct, then an inverted (back-to-front) configuration of Piezo1 in the wall (or cuticular plate) of an outer hair cell (specifically OHC2) would be a simple way of providing both sorts of polarities.

The significance here is that the channels might, if sufficiently sensitive, be activated by alternating pressure variations - sound - in the cochlear fluid, with resonance occurring in sympathy with common-mode pressure, not the differential pressure associated with traveling wave dynamics. There are various interesting properties of the reversepolarity channels, including their appearance and disappearance during development (just like kinocilia do), but the outstanding property is the reversal of polarity compared to standard channels. Working in concert, standard and reversed channels could provide an efficient electromechanical drive to the cochlear amplifier. A propeller would rotate in one direction during the positive phase of a sound waveform (when the stapes moves in) and in the reverse direction during the negative phase (when the stapes moves out), a process which, if mirrored in adjoining rows, could establish a xylophone-like resonance between the rows of outer hair cells (Figure 2). In this way, Helmholtz's resonance idea might be physically realized, although at this stage the details are lacking.

\section{Conclusion}

In this brief historical perspective there has not been room to discuss the contributions of other eminent otologists such as Politzer, Lucae, Henke, and the like (but see (43) and its references). A major point of this paper is that 19thcentury otologists made important contributions which, for good reasons or bad, have fallen by the wayside.

Nineteenth-century otology applied new scientific instruments and methods to the study of the human ear and discovered novel phenomena and principles. Its practitioners were acute and had fine observational skills, and there is much in the early literature to engage us. This paper has highlighted the intralabyrinthine pressure theory of middle ear muscle action, which was an established principle at the end of the century, and which had considerable explanatory power. The surprise is how some theories faded away for more than a century, only to make a recent reappearance. Modern scientific techniques perhaps offer a way to noninvasively measure subtle variations of hydraulic pressure within the cochlea. At the same time, the resonance theory of Helmholtz also deserves renewed attention, with a number of modern discoveries lending it support. The general lesson might be that there is much in the early literature which deserves a second look.

\section{Acknowledgments}

This work received support from the Institute of Physiology and Pathology of Hearing, Warsaw (contract 109/ IFPS/2017).

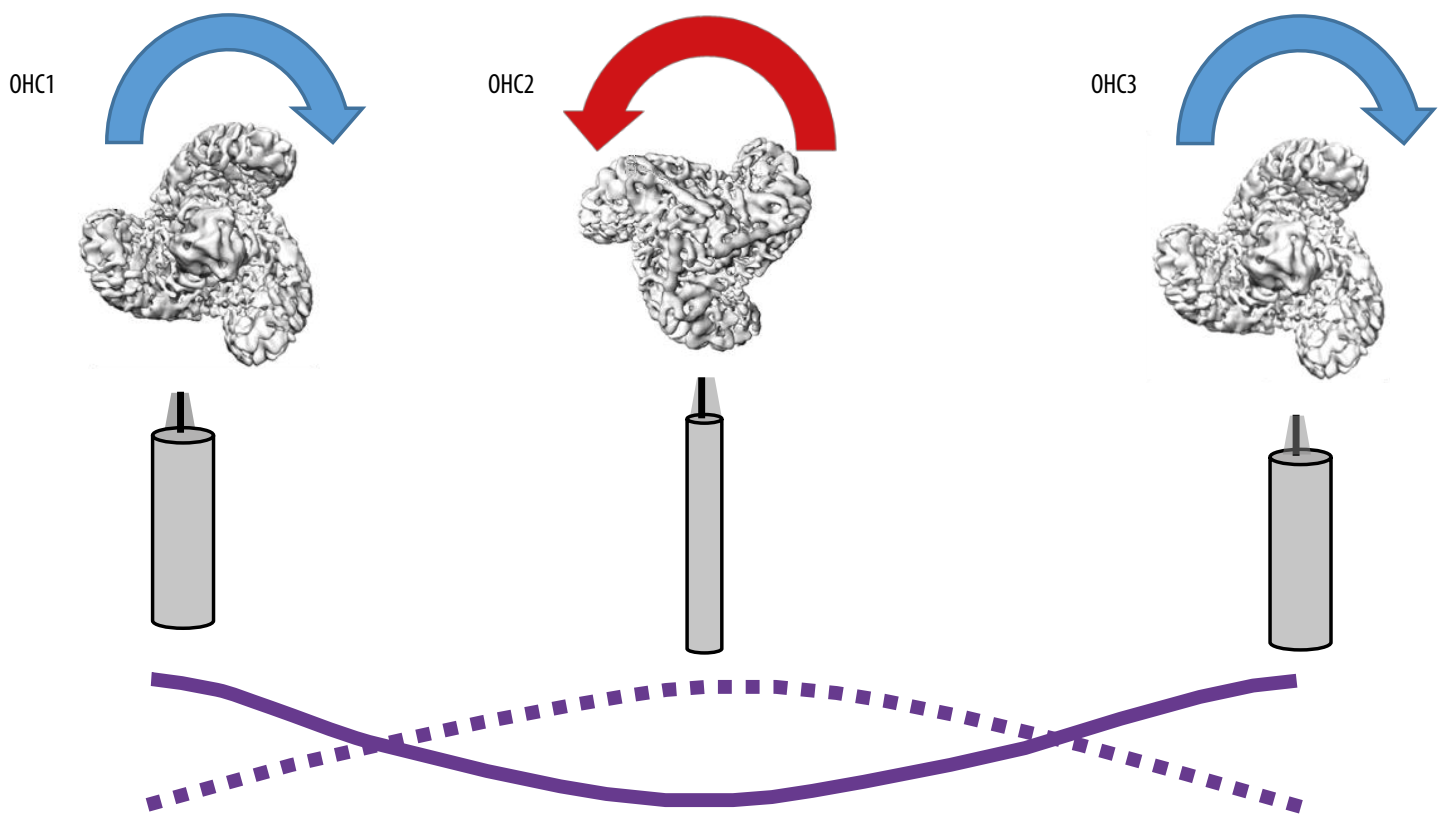

Figure 2. How alternating polarity of rows of outer hair cells $(\mathrm{OHC} 1, \mathrm{OHC} 2$, and $\mathrm{OHC} 3)$ could lead, via electromotility, to a vibrational standing wave (bottom) between the rows. Here, in response to sound pressure, OHC2 undergoes reversed electromotile length changes (e.g. a lengthening) compared to $\mathrm{OHC} 1$ and $\mathrm{OHC} 3$ (shortening), a reversal conferred by the inverted placement of the propeller-like Piezo1 channel. The result of the concerted wave-generating action of the three OHCs is to create antinodes at the position of the OHCs (as in a xylophone bar or wind chime) and this standing wave can be considered the cochlea's resonating element. 
1. Helmholtz HLFv. On the Sensations of Tone as a Physiological Basis for the Theory of Music. London: Longmans, Green; 1875.

2. Bell A. How do middle ear muscles protect the cochlea? Reconsideration of the intralabyrinthine pressure theory. Journal of Hearing Science 2011;1(2):9-23.

3. Franz P, Hamzavi JS, Schneider B, Ehrenberger K. Do middle ear muscles trigger attacks of Ménière's disease? Acta Otolaryngol 2003;123:133-7.

4. Loader B, Beicht D, Hamzavi J-S, Franz P. Tenotomy of the middle ear muscles causes a dramatic reduction in vertigo attacks and improves audiological function in definite Meniere's disease. Acta Otolaryngologica 2012;132:491-7.

5. Loader B, Beicht D, Hamzavi J-S, Franz P. Tenotomy of the stapedius and tensor tympani muscles reduces subjective dizziness handicap in definite Meniere's disease. Acta Otolaryngologica 2013;133:368-72.

6. Bell A. Middle ear muscle dysfunction as the cause of Meniere's disease. Journal of Hearing Science 2017;7(3):9-25.

7. Bell JA. The Underwater Piano: A Resonance Theory of Cochlear Mechanics. PhD thesis, Australian National University, Canberra 2005.

8. Bell A. Resonance theories of hearing: a history and a fresh approach. Acoustics Australia 2004;32:108-13.

9. Bell A. A resonance approach to cochlear mechanics. PLOS One 2012;7:e47918.

10. Li W, Gao N, Yang M. The structural basis for sensing by the Piezol protein. Current Topics in Membranes 2017;79:135-58.

11. Ge J, Li W, Zhao Q, Li N, Chen M, Zhi P, Li RC, Gao N, Xiao B, Yang M. Architecture of the mammalian mechanosensitive Piezol channel. Nature 2015;527:64-9.

12. Beurg M, Goldring AC, Ricci AJ, Fettiplace R. Development and localization of reverse-polarity mechanotransducer channels in cochlear hair cells. Proc Nat Acad Sci 2016;113:6767-72.

13. Bell A. The cochlea, surface acoustic waves, and resonance. In: Jabbari E, Kim D-H, Lee LP, Ghaemmaghami A, Khademhosseini A, editors. Handbook of Biomimetics and Bioinspiration. Singapore: World Scientific; 2014. p. 719-41.

14. Bell A, Wit HP. Cochlear impulse responses resolved into sets of gammatones: the case for beating of closely spaced local resonances. PeerJ 2018;6:e6016.

15. Borg E, Counter SA, Rösler G. Theories of middle-ear muscle function. In: Silman S, editor. The Acoustic Reflex: Basic Principles and Clinical Applications. New York: Academic Press; 1984 p. 63-99.

16. Bell A. Detection without deflection? A hypothesis for direct sensing of sound pressure by hair cells. Journal of Biosciences 2007;32:385-404.

17. Bell A. The pipe and the pinwheel: is pressure an effective stimulus for the 9+0 primary cilium? Cell Biol Int 2008;32:462-8.

18. Beasley NJP. Meniere's disease: evolution of a definition. J Laryngol Otol 1996;110:1107-13.

19. Storper IS. Meniere's syndrome. In: Rowland LP, Pedley TA, editors. Merritt's Neurology (12th ed). Philadelphia: Lippincott Williams \& Wilkins; 2010. p. 963-6.

20. Weber-Liel FE. Tenotomy of the tensor tympani [English translation of Weber 1872 by A. Loos and L. Turnbull]. Medical and Surgical Reporter 1873;28:221-5; 39-41.

21. Pullens B, Verschuur HP, Benthem PP. Surgery for Meniere's disease (review). Cochrane Database of Systematic Reviews 2013:CD005395.

22. Hallpike CS, Cairns H. Observations on the pathology of Meniere's syndrome. J Laryngol Otol 1938;53:625-55.
23. Jerin C, Floerke S, Maxwell R, Gurkov R. Relationship between the extent of endolymphatic hydrops and the severity and fluctuation of audiovestibular symptoms in patients with Meniere's disease and MRI evidence of hydrops. Otology and Neurotology 2017;39:e123-e30.

24. Gurkov R, Jerin C, Flatz W, Maxwell R. Clinical manifestations of hydropic ear disease (Meniere's). Eur Arch Otorhinolaryngol 2019;276(1):27-40.

25. Lopez-Escamez JA, Carey J, Chung W-H, Goebel JA, Magnusson M. Diagnostic criteria for Meniere's disease. J Vestib Res 2015;25:1-7.

26. Weber-Liel FE. Ueber die Zwecke, die Wirkung und die Ausfuhrung der Tenotomie des M. tensor tympani. Monatsschr Ohrenheilkd Laryngorhinol 1872;6:1-8.

27. Bürkner K. Die Fortschritte in der Therapie der Ohrkrankheiten im letzen Decennium (1870-1879). Archiv für Ohrenheilkunde $1882 ; 19: 1-27$.

28. Burnett $\mathrm{CH}$. The Ear: Its anatomy, physiology, and diseases. Philadelphia: Henry C. Lea; 1877.

29. Macnaughton Jones H. A Treatise on Aural Surgery, Second Edition. Dublin: Fannin \& Co.; 1881.

30. Turnbull L. Tenotomy of the tensor-tympani. Medical and Surgical Reporter 1877;36:51-3.

31. Bell A. Hearing: travelling wave or resonance? PLoS Biology 2004;2:e337.

32. Bell A, Wit HP. The vibrating reed frequency meter: digital investigation of an early cochlear model. PeerJ 2015;3:e1333.

33. Helmholtz HLFv. The mechanism of the ossicles and the membrana tympani [translated by J. Hinton]. New Sydenham Society Series 1874;62:97-155.

34. Kirikae I. An experimental study on the fundamental mechanism of bone conduction. Acta Otolaryngologica 1959;Supplement 145:1-111.

35. Lim DJ. Functional structure of the organ of Corti: a review. Hear Res 1986;22:117-46.

36. Greene NT, Jenkins HA, Tollin DJ, Easter JR. Stapes displacement and intracochlear pressure in response to very high level, low frequency sounds. Hear Res 2017;348:16-30.

37. Bell A. The cochlea as a graded bank of independent, simultaneously excited resonators: calculated properties of an apparent 'travelling wave'. Proceedings of the 20th International Congress on Acoustics 2010.

38. Bell A. Are outer hair cells pressure sensors? Basis of a SAW model of the cochlear amplifier. In: Gummer AW, editor. Biophysics of the Cochlea: From Molecules to Models. Singapore: World Scientific; 2003. p. 429-31.

39. Bell A. Sensors, motors, and tuning in the cochlea: interacting cells could form a surface acoustic wave resonator. Bioinsp Biomim 2006;1:96-101.

40. Bell A. Tuning the cochlea: wave-mediated positive feedback between cells. Biol Cybern 2007;96:421-38.

41. Bell A, Fletcher NH. The cochlear amplifier as a standing wave: "squirting" waves between rows of outer hair cells? J Acoust Soc Am 2004;116:1016-24

42. Bell A. Reptile ears and mammalian ears: hearing without a travelling wave. Journal of Hearing Science 2012;2(3):14-22.

43. Nogueira Júnior JF. A brief history of otorhinolaryngology. Rev Bras Otorrinolaringol 2007;73:693-703. 